\title{
Adictos a la vida
}

MARTA GILI

Fundación "la Caixa". Barcelona

Mirar al otro es una de las maneras de mirarse a sí mismo. Observar detenidamente cómo los demás se desenvuelven en el mundo significa, también, situarnos a nosotros mismos en un determinado contexto, aprender a tener conciencia de quiénes somos y explorar nuestra propia cultura de procedencia. En definitiva, curiosear en la vida de los demás supone establecer una medida para la nuestra y poner en tela de juicio nuestras propias pautas de conducta.

La fotografía ha sido considerada tradicionalmente como un inestimable instrumento de observación. Y de hecho así ha sido desde su invención en 1839. El milagro de la fotografía consistió, en aquel entonces, en apoderarse de la realidad exterior, limitarla al formato del ojo mecánico y difundir la mayor cantidad posible de imágenes del mundo: desde lo más íntimo y familiar hasta lo más exótico y desconocido.

Apareció así el fotógrafo aventurero, el emisario de la mirada, que recorría el orbe en busca del otro; de lo diferente, pero también de lo común, de lo ausente pero también de lo intuido. Su curiosidad no tenía límites y su ansia por fotografiarlo todo le transformó en una especie de corsario moderno, saqueador de la realidad, mostrando orgulloso su botín repleto de un montón de imágenes robadas en sus incursiones.

Hasta aquí el fotógrafo actuaba según su intuición personal, sus gustos, sus pasiones, su capacidad de encantamiento. Pronto, sin embargo, surgió otro tipo de miradas que, impulsadas por el saber organizado, acudieron a la fotografía como instrumento de observación científica del otro. Algunos antropólogos, etnógrafos, arqueólogos e historiadores optaron por recuperar la parte más descriptiva y funcional de la fotografía. Ésta debía mostrar de una manera limpia y clara sus objetos de estudio. En este momento, el fotógrafo, a veces "científico", a veces al servicio de unas consignas dadas por los científicos, registró el mundo con una mirada más aséptica, más neutral y por lo tanto más ajustada a los cánones de la rigurosidad y de la eliminación de variables personales que distorsionaran el resultado de las investigaciones de campo. 
La fotografía como un "bloc de notas" pronto se demostró como insuficiente. La grandeza de la imagen fotográfica residía precisamente en aquello que se pretendía anular: su versatilidad, su capacidad de sugerir, de provocar, de apuntar, en definitiva, de interpretar. La fotografía narraba sin ser necesariamente un instrumento narrativo. Sin embargo, precisamente en esos intervalos no narrativos yacía el esplendor de la conquista del saber. En esta especie de reconstrucción de los hechos, la fotografía jugaba un papel importante para la antropología y las ciencias sociales en general. El fotógrafo con su mirada intuitiva y el investigador con su contemplación empírica formaban un equipo que abarcaba los dos ámbitos de cualquier experiencia: la realidad y la ficción.

Un ejemplo de esta fructífera asociación intelectual entre un fotógrafo y un científico lo encontramos en los primeros trabajos que Eadweard Muybridge realizó en 1887. Muybridge en su Animal Locomotion realizó un trabajo sobre los efectos estético-artísticos de la descomposición en imágenes del movimiento de los seres vivos. Las primeras investigaciones de Muybridge allá por el año 1880 llegaron a oídos del fisiólogo Marey quien se entusiasmó por las posibilidades científicas de este trabajo. A partir de los trabajos de Muybridge, Marey inició un minucioso estudio en el que analizaba, a partir de 12 imágenes por segundo, la estructura y la cadencia del movimiento en distintos animales. Su metodología registraba en un gráfico las sucesivas variaciones del movimiento en el espacio y el tiempo. Marey descubrió así en la fotografía un instrumento de registro y de medida de excepcional precisión. Este es un buen ejemplo del eterno pulso entre arte y ciencia, que afortunadamente todavía subsiste.

John Collier, en una apasionada defensa de la fotografía como instrumento imprescindible para los estudios antropológicos, cree que la cámara es una extensión del ojo humano y que le sustituye, complementa y supera en capacidad. Considera que el lenguaje no verbal del foto-realismo es el lenguaje más comprendido interculturalmente y transculturalmente ${ }^{1}$. Evidentemente, como el propio Collier admite, la fotografía no solo es un utensilio para tomar notas de aquello que de antemano ya se ha descubierto por otros medios, sino que a través de la imagen, el estudioso puede llegar más lejos en su investigación sobre el ser humano y su cultura.

Muchos han sido los estudiosos que han tratado el tema de las relaciones entre fotografía y antropología. Y por ello no desearía extenderme en este tema. En numerosas ocasiones, tanto el fotógrafo como el

1 John Coluer, Visual Anthropology: Photography as a Research Method (New York: Holt, Rinehart and Winston, Inc., 1967). 
antropólogo han sabido cómo interrelacionar sus trabajos de una forma provechosa para ambos. Sin embargo, cuando Collier escribió esto, hacia finales de los años sesenta, no podía ni imaginar que la fotografía o lo que él denominaba "el foto-realismo" llegaría a tal grado de transculturalidad que se convertiría por sí misma en un símbolo vacío de contenido. Y además, que los usos que los artistas contemporáneos han hecho de la fotografía desde principios de los setenta hasta nuestros días se encuentran bastante lejos de lo que él consideraba como "realista".

Si bien es cierto que fotógrafos documentalistas de la talla de Sebastião Salgado o Cristina García Rodero se apoderan todavía de la mirada del gran público con sus fabulosas imágenes, a mitad de camino entre la epopeya personal y el clasicismo documentalista, creo que cada vez son menos las imágenes de este cariz que puedan llegar a ofrecernos un profundo conocimiento de la cultura y de la forma de comprender el mundo de los demás. Tal vez por ello muchos artistas-fotógrafos han optado por explorar el mundo desde otras perspectivas, quizá menos obvias desde el punto de vista del documentalismo tradicional, pero posiblemente más acordes con los planteamientos y las inquietudes contemporáneas. Propongo pues una, breve y nada exhaustiva, aproximación a la fotografía contemporánea, como testigo ilustrativo de comportamientos sociales, culturales, personales y colectivos del momento actual.

Evidentemente, como en el caso de Muydbridge, son trabajos donde el componente estético juega un papel muy importante. Sin embargo, todas estas obras se sumergen en la voluntad última de comprender y de analizar la complejidad de las relaciones del ser humano con su entorno físico y psíquico. Son obras donde la etnografía, la arqueología, la antropología cultural, la antropología biológica, la antropología social e incluso la lingüística pueden tener algo que decir.

En 1928, el fotógrafo alemán Albert Renger Patszch publicó uno de los libros más emblemáticos de la historia de la fotografía de este siglo, Die Welt ist Schön ${ }^{2}$ (El mundo es bello). A partir de las premisas de "Die Neue Sachlichkeit" (La nueva objetividad"), Renger Patszch se permitió la libertad de analizar fotográficamente el mundo de las cosas, su naturaleza y su forma. Era como un catálogo de objetos y paisajes, de naturaleza en estado puro, versus naturaleza producida por el hombre, extraídos con una "fotografía fotográfica" - la expresión es suya - en oposición a la fotografía pictorialista, más amanerada y esteticista que imperaba hasta ese momento en toda Europa. Se trataba de una fotografía directa, limpia, donde el principal objetivo era mostrar las cosas en su misma esencia, hasta donde

\footnotetext{
2 Die Welt ist Schön (Munich: Kurt Wolf Verlag, 1928).
} 
el ojo humano no pudiera llegar. Esta especie de neo-realismo fotográfico inició rápidamente toda una escuela de seguidores y acólitos de los que hoy muchos artistas son todavía deudores.

Impactante fue el trabajo del también alemán August Sander. Con la misma precisión meticulosa de Renger Patzsch, Sander concibió la idea de un archivo monumental. El título de su trabajo iba a ser "La Humanidad del siglo $\mathrm{XX}^{\prime}$, una especie de archivo de retratos de todo el mundo. Sin embargo, por razones obvias, su trabajo se circunscribió a la gente de su entorno regional. Esta obra ${ }^{3}$ presenta un estudio meticuloso de los arquetipos humanos. Sus cerca de 550 retratos tienen el mérito, no solo de fotografiar toda una generación de alemanes de antes de la segunda guerra mundial, sino de presentar tanto su posición social como individual. Sander trataba los rostros de sus personajes con el mismo cuidado que el entorno en el que los fotografiaba, sus vestidos, los objetos que los rodeaban, etc. Un estudio exhaustivo y pormenorizado de esta gran colección de retratos no puede dejar escapar su utilidad sociológica y cultural para comprender una época. A pesar de que el artista mismo for-

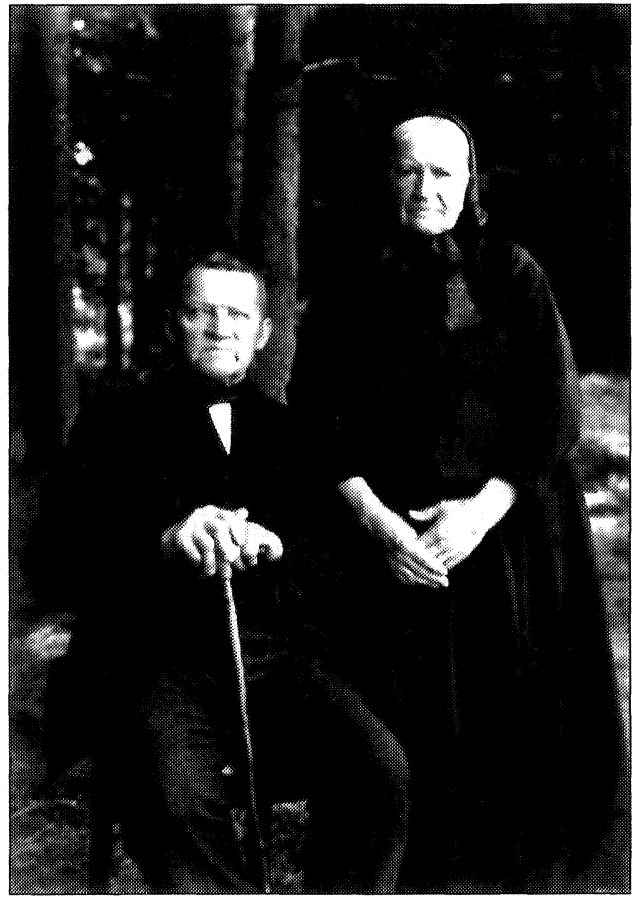

FIG. 1.-August Sander. 1911. maba parte del entorno, su capacidad para objetivar sus sujetos merece especial atención. Ante sus fotografías uno no puede dejar de pensar que se trata de personajes que, desafortunadamente, se convirtieron en el centro de uno de los dramas más escalofriantes de este siglo.

Tanto Renger Patszch, como Sander y otros fotógrafos adscritos a la corriente artística de la Nueva Objetividad son, sin duda alguna, inspiradores de un cierto tipo de fotografía que se extiende hoy en día por el panorama de la creación artística. Los trabajos de Bernd y Hilla Becher son un buen ejemplo.

¿Qué sucede cuando a las construcciones industriales se les denomina y se las fotografía

\footnotetext{
3 Deutschenspiegel: Menschen des 20 Jabrhundert, Munich, 1929-Guntersloh, 1962.
} 
como "esculturas anónimas" «? Que las fotografías del matrimonio Becher se convierten en objeto de estudio arqueológico. Sus imágenes son, como las de Sander, puros documentos visuales, pruebas de los procesos históricos del desarrollo de la humanidad. Por supuesto, no se trata de documentos de registro puro y simple. Los trabajos de los Becher (torres de agua, tanques de gas, silos, fábricas de todo tipo o conducciones de agua) tienen una intencionalidad concreta. Su interés no son los paisajes pintorescos de la Alemania industrial, sino el análisis de las estructuras de estos elementos industriales y por extensión de los hombres que las han hecho posibles. Sander y Renger Patszch pretendían lo mismo con sus retratos u objetos: descripción, catalogación y sistematización de la naturaleza del hombre. Estos trabajos que por mucho tiempo fueron poco comprendidos por los ambientes fotográficos de la época, tienen mucho que ver con una mirada "científica" y a la vez personal del mundo que nos rodea y de quienes lo construyen, reconstruyen o destruyen.

Siguiendo la línea iniciada por estos tres fotógrafos, otros artistas contemporáneos alemanes han buceado en esta necesidad de presentar el mundo de una manera fría, autoanalítica y distante que tanto caracteriza a sus trabajos. Las fotografías de Roland Fisher, por ejemplo, son retratos en serie de seres humanos en los que la variable del contexto está siendo controlada en extremo. Esta colección de personajes presenta toda una galería de sentimientos, de emociones, que va más allá de las eventualidades del lugar o del espacio. Son objetos humanos en los que la materia de estudio podría ser, probablemente, la soledad del hombre y la mujer contemporáneos.

En un momento en el que, política y socialmente, conceptos como "globalización" o "fragmentación" están a la orden del día, no podía faltar la aportación de artistas que se interrogan sobre temas como la identidad nacional, sus límites y su auténtico significado. El fotógrafo irlandés, Mick O'Kelly, propone en "Ellos y nosotros" una reflexión sobre si las identidades se definen con símbolos (como banderas, monedas o lengua propia) o si su arraigo trasciende la noción de frontera, creando nuevos significados. O'Kelly se pregunta ¿existe el auténtico irlandés?, ¿hasta qué punto en el tiempo deberíamos retroceder para llamar todavía a un predecesor «irlandés"?

Efectivamente, uno de los temas más recurrentes en la fotografía contemporánea es el de la identidad. La identidad sexual, familiar, social, cultural, racial, nacional... El ubicarse a sí mismo con respecto al otro es

4 Anonyme Skulpturen: eine typologie Technische Bauten (Düsseldorf: Art-Press, 1979). 
quizá una de las estrategias más utilizadas para llegar a responder a las famosas preguntas de "quién somos, a dónde vamos y de dónde venimosn. Preguntas que nadie ha podido responder satisfactoriamente nunca, y que quizá sean el nódulo central o la espita de cualquier investigación personal o científica, y también filosófica.

Jorma Puranen, un artista finlandés, se plantea cuestiones que mucho tienen que ver con la antropología y la apología de la clasificación y el archivo. Puranem encontró en el Musée de l'Homme en París una serie de retratos fotográficos realizados en una expedición etnográfica y antropológica el año 1882 en el norte de Laponia. Estas fotografías presentaban algunos de los habitantes de esta zona, casi todos de la minoría sami. En su investigación en estos archivos Puranen encontró retratos de padres, madres, abuelos y muchos otros parientes de algunas de las familias que él conocía personalmente. Así que decidió reproducir estas fotografías, ampliarlas a un formato de tamaño real sobre un metacrilato y situarlas en los paisajes del norte de Noruega y Suecia, ahí donde los documentos y las historias de los descendientes de los sami indicaban que estos pobladores habían vivido. Una vez finalizada esta instalación re-fotografió la escena: los personajes fueron devueltos a su paisaje de origen, a través de su retrato. La idea era imaginar un retorno metafórico de este pueblo, enterrado en los archivos de la historia y de la fotografía, a la cultura y a los paisajes de los cuales fueron en su día separados. El interés de este trabajo radica también en una reflexión sobre cómo y de qué forma miramos y fotografiamos el mundo más allá de nuestra cultura.

Otra artista emblemática de finales de este siglo es Cindy Sherman y su, no menos conocido, trabajo "Film Still Lifes". Sherman explora los estereotipos femeninos creados a partir de personajes arquetípicos de la filmografía "hollywoodiana" de los años cincuenta. Se trata de un estudio psicológico y sociológico pormenorizado de la imagen y del rol que la sociedad otorga a la mujer, en el que Sherman se autorretrata "actuando" según estos patrones. El papel de los mass-media en la adopción de pautas de conducta y en la formación de una determinada noción de la realidad es, por supuesto, uno de los temas más tratados por toda una serie de artistas, como la propia Cindy Sherman, pero también muchos otros, cuyo objetivo es apuntar o plantear situaciones o reflexiones que se encuentran en el ojo del huracán de la actualidad.

Un tipo distinto de experiencia narrativa con la fotografía es el trabajo de Nan Goldin. Goldin fotografía su espacio doméstico, sus amigos y las relaciones especiales de interdependencia que se establecen entre ellos. Tras más de veinte años fotografiando su entorno, las imágenes de Goldin se han convertido en un referente visual esencial para analizar las inquie- 
tudes existenciales de sectores marginales de Nueva York y sus alrededores, alejados de las pautas de conducta de la burguesía convencional y rutilante de esta ciudad. La violencia, la agresividad, la prostitución, la homosexualidad, la duda, el desenfreno, el desamor son temas que quedan magistralmente tratados en esta obra.

"La razón habla y el sentido muerde", decía Petrarca. "Y muerde en el cogollo del corazón", añadía Unamuno. Es el corazón, la sensibilidad, los sentimientos y la emotividad el terreno sobre el que cavan los artistas. A partir de ahí, la antropología puede recoger las propuestas y someterlas a cuantas transformaciones considere necesarias. Despreciar la materia prima de estos adictos observadores de la vida, sería como seguir creyendo que somos animales racionales. Y hoy en día, ya casi todo el mundo sospecha lo que, hace décadas, anunciaba Unamuno: "lo real, lo realmente real, es irracional; y la razón construye todas las irracionalidades" 5 .

El artículo explora el valor antropológico de la fotografía profesional contemporánea. La antropología, disciplina abierta por su misma definición al conocimiento de lo humano, puede recoger las propuestas de aquélla y someterlas a cuantas transformaciones considere necesarias. En la actualidad, no se puede despreciar la materia prima que ofrece la fotografía profesional y artística, ya que aportan un caudal ingente de información, de conocimiento y de reflexión.

The author assesses the anthropological value of contemporary professional photography. Anthropology, which by definition is the study of anything human, can receive whatever proposals that professional photography has to offer and subject them to the transformations that the discipline may deem necessary. Nowadays, anthropologists cannot turn down the data that professional photography can supply, because it is a rich source of information and reflection.

5 Miguel DE UnAmuno, El sentimiento trágico de la vida (Madrid: Ed. Óptima, 1997), p. 50. 